Letter to the Editor

\title{
Bone marrow transplantation with Favorable outcome in three patients with LPS-responsive beige- like anchor (LRBA) deficiency
}

Common variable immunodeficiency (CVID) is a highly heterogeneous group of disorders that is characterized by defective antibody production, recurrent infections, lymphoproliferation and autoimmunity. Although hematopoietic stem cell transplantation (HSCT) is accepted as a standard treatment modality for long-term resolution for many forms of severe primary immunodeficiencies (PIDs), its role is not well established in patients diagnosed with CVID [except for cases with treatment-resistant severe complications or diagnosis of cancer]. Autosomal recessive mutations in LRBA, encoding LPS-responsive beige-like anchor protein were first described as a cause of CVID-like disease in $2012[1,2]$. Allogeneic HSCT has been performed only in a few severely affected patients with LRBA deficiency in whom it induced/resulted in complete or partial response [3-8]. We report the detailed transplant course of three Turkish patients with LRBA deficiency who presented with a large spectrum of severe clinical manifestations and were treated by allogeneic HSCT (alloHSCT).

\section{Patient 1}

14 year-old boy who was born to consanguineous parents and became symptomatic at the age of 6 months. He was hospitalized several times due to recurrent pulmonary infections. At the age of four, he developed pancytopenia, lymphadenopathy, hepatosplenomegaly and autoimmunity (autoimmune hemolytic anemia and autoimmune thyroiditis) with low serum immunoglobulin levels. As a result, he received several courses of immunosuppressive therapy, including methylprednisolone and high-dose IVIG besides broad-spectrum antibiotics since he suffered from recurrent infections. By the age of 10, he was diagnosed with inflammatory bowel disease (IBD)-like colitis, which was presented with recurrent episodes of bloody diarrhea and was partially responsive to immunosuppressive therapy, mesalazine and gluten-free diet. He suffered from a poor appetite, malabsorption and secondary Cushing's syndrome and failure to thrive (weight and height for age $<3 p$ ). Combined homozygosity mapping and exome sequencing for CVID candidate genes performed, prior to HSCT revealed a homozygous single nucleotide deletion in the LRBA gene (c.5527delT:p.C1843fs). Due to the rapid increase in severe CVID-related complications, alloHSCT was performed at the age of 14 years. Bone marrow stem cells $\left(4.4 \times 10^{8}\right.$ total nucleated cells $/ \mathrm{kg}$ and $3.2 \times 10^{6}$ $\mathrm{CD} 34+$ cells $/ \mathrm{kg}$ ) from his heterozygous HLA-identical brother were used after the patient underwent a reduced intensity conditioning regimen including fludarabine $\left(40 \mathrm{mg} / \mathrm{m}^{2} /\right.$ day -6 to -3 ) and busulfan ( $4.9 \mathrm{mg} / \mathrm{kg} /$ day -6 to -3 ). ATG-F (grafalon) was given on days -6 to -3 (30 mg $/ \mathrm{kg}$, overall dose) as GvHD prophylaxis along with cyclosporin A (CSA) and low-dose methotrexate $\left(10 \mathrm{mg} / \mathrm{m}^{2} /\right.$ dose, day $+1,+3$ and $+6)$. Neutrophil and thrombocyte recovery delayed significantly and occurred on day +44 and +92 , respectively. Severe intractable colitis with hypoalbuminemia continued until the engraftment despite vigorous fluid-electrolyte replacement therapy, and was accompanied with severe episodes of acute gastrointestinal bleeding. As a result, patient received prolonged total parenteral nutrition. Diarrhea episodes resolved completely without any recurrence after the achievement of full donor chimerism at day +30 . He developed hepatic veno-occlusive disease, which was successfully treated with defibrotide and strict fluid restriction. Several episodes of infections, including catheter-related blood stream infections, candida- and gram-negative bacteria-caused sepsis and CMV reactivation occurred and treated successfully. Three doses of Abatacept by 2-week intervals were administered in early posttransplant period due to persistent severe cytopenia considering the potential to develop immune cytopenia [as a result of unresolved disease-related immune dysregulation] [2]. A CD34 + stem cell boost was planned to improve poor graft function that has most likely resulted from complicated transplant course and infections, but was not administered thanks to spontaneous recovery of cell counts. He was hospitalized several times because of catheter-related infections, pneumonia, and acute cholecystitis episodes and underwent surgery for perforated acute appendicitis within the first year post- transplant. All these infections accompanied with severe cytopenia (neutropenia and thrombocytopenia). Thus, he received prolonged courses of parenteral antibiotics together with IVIG, high-dose steroid and G-CSF. Around second year post-transplant, T, B and NK cell counts and Ig serum levels have become stabilized, although lower than the reference values, without any recurrence of autoimmune symptoms (Table 1). He is currently at thirthy-five months post-transplant with stable full donor chimerism and in good clinical condition with no signs of GvHD. He is on normal diet and has gained weight and height. He is receiving IVIG prophylaxis, thyroid hormone, hydrocortisone replacement and bisphosphonate for osteoporosis. Immune suppressive therapy was discontinued at 36 months post-transplant. Resolution of primary disease after HSCT therefore appears to be related to immunological recovery besides stable full donor chimerism.

\section{Patient 2}

An 18 year-old girl initially presented with chronic diarrhea, intermittent fever and recurrent pneumonia at the age of one year. She developed an autoimmune lymphoproliferative syndrome (ALPS)-like clinical picture (hepatosplenomegaly, lymphadenopathy and immune cytopenia) at around 10 years of age. Then she was referred to our institution for a potential diagnosis of primary immunodeficiency considering the history of parental consanguinity and loss of infant siblings due to sepsis. She suffered from mastoiditis and CMV pneu- 
Table 1

Cellular and serological parameters pre-and post-HSCT.

\begin{tabular}{|c|c|c|c|c|c|c|}
\hline & \multicolumn{2}{|c|}{ Patient 1} & \multicolumn{2}{|c|}{ Patient 2} & \multicolumn{2}{|c|}{ Patient 3} \\
\hline & Pre-HSCT & Post-HSCT $^{\mathrm{a}}$ & Pre-HSCT & Post-HSCT ${ }^{\mathrm{a}}$ & Pre-HSCT & Post-HSCT ${ }^{\mathrm{a}}$ \\
\hline $\begin{array}{l}\text { Lymphocyte subsets } \\
\quad \text { (cells } / \mu \mathrm{L}) \mathrm{CD}^{+} \mathrm{T} \text { cells }\end{array}$ & $\begin{array}{l}103 \\
(1033-3305)\end{array}$ & $\begin{array}{l}1077 \\
(1024-2794)\end{array}$ & $\begin{array}{l}734 \\
(1024-2794)\end{array}$ & $\begin{array}{l}405 \\
(1024-2794)\end{array}$ & $\begin{array}{l}961 \\
(1033-3305)\end{array}$ & $\begin{array}{l}1837 \\
(1024-2794)\end{array}$ \\
\hline $\mathrm{CD}^{+}{ }^{+} \mathrm{CD} 4^{+}$ & $\begin{array}{l}34 \\
(504-1777)\end{array}$ & $\begin{array}{l}205 \\
(621-1632)\end{array}$ & $\begin{array}{l}433 \\
(621-1632)\end{array}$ & $\begin{array}{l}170 \\
(621-1632)\end{array}$ & $\begin{array}{l}356 \\
(504-1777)\end{array}$ & $\begin{array}{l}588 \\
(621-1632)\end{array}$ \\
\hline $\mathrm{CD}^{+} \mathrm{CD}^{+}$ & $\begin{array}{l}39 \\
(381-1313)\end{array}$ & $\begin{array}{l}829 \\
(270-1255)\end{array}$ & $\begin{array}{l}184 \\
(270-1255)\end{array}$ & $\begin{array}{l}203 \\
(270-1255)\end{array}$ & $\begin{array}{l}471 \\
(381-1313)\end{array}$ & $\begin{array}{l}1102 \\
(270-1255)\end{array}$ \\
\hline $\mathrm{CD}_{19}{ }^{+}$ & $\begin{array}{l}0 \\
(94-793)\end{array}$ & $\begin{array}{l}55 \\
(87-540)\end{array}$ & $\begin{array}{l}70 \\
(87-540)\end{array}$ & $\begin{array}{l}70 \\
(87-540)\end{array}$ & $\begin{array}{l}15 \\
(94-793)\end{array}$ & $\begin{array}{l}167 \\
(87-540)\end{array}$ \\
\hline $\mathrm{CD} 16^{+} \mathrm{CD} 6^{+}$ & $\begin{array}{l}46 \\
(94-1175)\end{array}$ & $\begin{array}{l}77 \\
(100-640)\end{array}$ & $\begin{array}{l}61 \\
(100-640)\end{array}$ & $\begin{array}{l}65 \\
(100-640)\end{array}$ & $\begin{array}{l}160 \\
(94-1175)\end{array}$ & $\begin{array}{l}358 \\
(100-640)\end{array}$ \\
\hline $\begin{array}{l}\mathrm{CD}^{+}{ }^{+} \mathrm{CD} 4^{+} \mathrm{CD} 45 \mathrm{RA}^{+} \\
\quad\left(\% \text { of } \mathrm{CD} 3^{+} \mathrm{CD} 4^{+} \text {cells }\right)\end{array}$ & ND & $17 \%$ & ND & $72 \%$ & ND & $34 \%$ \\
\hline $\begin{array}{l}\mathrm{CD}^{+} \mathrm{CD}^{+} \mathrm{CD}^{2} 5 \mathrm{RA}^{+} \\
\quad\left(\% \text { of } \mathrm{CD} 3^{+} \mathrm{CD}^{+} \text {cells }\right)\end{array}$ & ND & $1,5 \%$ & ND & $7 \%$ & ND & $3 \%$ \\
\hline$\alpha \beta \mathrm{TCR}^{+} \mathrm{CD}^{+}$ & ND & $98 \%$ & ND & $90 \%$ & ND & $90 \%$ \\
\hline$\gamma \delta \mathrm{TCR}^{+} \mathrm{CD}^{+}$ & ND & $1.5 \%$ & ND & $8 \%$ & ND & $9 \%$ \\
\hline TREC cells & ND & $9 \%$ & ND & $1 \%$ & ND & $5 \%$ \\
\hline Treg & ND & $0.7 \%$ & ND & $0.5 \%$ & ND & $2.4 \%$ \\
\hline $\mathrm{CD}^{-} \mathrm{CD} 16 / 56^{+} \mathrm{NK}$ cells & ND & $\begin{array}{l}73 \\
(100-640)\end{array}$ & ND & $\begin{array}{l}66 \\
(100-640)\end{array}$ & ND & $\begin{array}{l}358 \\
(100-640)\end{array}$ \\
\hline $\mathrm{CD} 19^{+} \mathrm{IgD}^{+} \mathrm{CD}_{27}{ }^{+}$ & ND & $88 \%$ & ND & $78 \%$ & ND & $64 \%$ \\
\hline $\begin{array}{l}\mathrm{CD} 19^{+} \mathrm{IgD}^{+} \mathrm{CD}^{+} 7^{+} \\
\quad\left(\% \text { of } \mathrm{CD} 19^{+} \text {cells }\right)\end{array}$ & ND & $4 \%$ & ND & $4 \%$ & ND & $3.5 \%$ \\
\hline $\begin{array}{l}\mathrm{CD} 19^{+} \mathrm{IgD}^{-} \mathrm{CD}^{2} 7^{+} \\
\quad\left(\% \text { of } \mathrm{CD} 19^{+} \text {cells }\right)\end{array}$ & ND & $2 \%$ & ND & $3 \%$ & ND & $23 \%$ \\
\hline Serum immunoglobulin (mg/dL) & & & & & & \\
\hline IgG & $\begin{array}{l}366 \\
(987-1958)\end{array}$ & $\begin{array}{l}1330 \\
(913-1884)\end{array}$ & $\begin{array}{l}794 \\
(913-1884)\end{array}$ & $\begin{array}{l}1110 \\
(913-1884)\end{array}$ & $\begin{array}{l}647 \\
(876-2194)\end{array}$ & $\begin{array}{l}940 \\
(913-1884)\end{array}$ \\
\hline IgM & $\begin{array}{l}4 \\
(83-282)\end{array}$ & $\begin{array}{l}25,3 \\
(88-322)\end{array}$ & $\begin{array}{l}114 \\
(88-322)\end{array}$ & $\begin{array}{l}190 \\
(88-322)\end{array}$ & $\begin{array}{l}27,6 \\
(75-448)\end{array}$ & $\begin{array}{l}60,9 \\
(88-322)\end{array}$ \\
\hline IgA & $\begin{array}{l}6.6 \\
(96-465)\end{array}$ & $\begin{array}{l}19,1 \\
(139-378)\end{array}$ & $\begin{array}{l}32,3 \\
(139-378)\end{array}$ & $\begin{array}{l}48,9 \\
(139-378)\end{array}$ & $\begin{array}{l}66 \\
(108-447)\end{array}$ & $\begin{array}{l}28,1 \\
(139-378)\end{array}$ \\
\hline $\begin{array}{l}\text { Donor chimerism }^{\mathrm{a}} \\
\text { Whole blood (\% of donor cells) }\end{array}$ & \multicolumn{2}{|c|}{$97 \%$} & \multicolumn{2}{|c|}{$93 \%$} & \multicolumn{2}{|c|}{$97 \%$} \\
\hline $\mathrm{T}$ cell (\% of donor cells) & \multicolumn{2}{|c|}{$92 \%$} & \multicolumn{2}{|c|}{$95 \%$} & \multicolumn{2}{|c|}{$99 \%$} \\
\hline
\end{tabular}

${ }^{\text {a }}$ At 35 months post-transplant for P1, at 20 months for P2 and at 23 months for P3.

monia during her follow up. The immunosuppressive treatment included high doses of steroids, multiple courses of IVIG, and CSA. The mycophenolate mofetil (MMF) was started at the age of 10 to treat severe refractory immune cytopenia and splenomegaly. This regimen resulted in partial remission of her symptoms. By the age of 17, she was diagnosed with occult HBV infection and lamuvidine therapy was started. After genetically confirmed diagnosis, she became candidate for allogeneic HSCT due to severe autoimmune disorder refractory to immunosuppresive therapy and organ toxicities from recurrent infections. Her pre-transplant immunology workup showed low levels of serum Ig $\mathrm{G}$ and $\mathrm{A}$, vaccine antibodies, and a mild B-cell lymphopenia with a persistent low numbers of $\mathrm{T}$ cells (Table 1 ). T lymphocyte proliferation and apoptosis assays were within normal limits. Healthy 13-year-old, HLA-identical sister served as her donor. The patient received unmanipulated bone marrow containing $3.8 \times 10^{8}$ total nucleated cells $/ \mathrm{kg}$ and $5.1 \times 10^{6} \mathrm{CD} 34+$ cells $/ \mathrm{kg}$ after she received reduced intensity conditioning regimen including fludarabine $\left(40 \mathrm{mg} / \mathrm{m}^{2} /\right.$ day -6 to -3$)$ and busulfan $(4.9 \mathrm{mg} / \mathrm{kg} /$ day -6 to -3 ). ATG-F (grafalon) was given on day -6 to $-3(30 \mathrm{mg} / \mathrm{kg}$, overall dose) as GvHD prophylaxis together with CSA and low-dose methotrexate. An uncomplicated engraftment was observed. Neutrophil and thrombocyte recovery occurred on days +22 and +50 , respectively. The patient developed an intermittent, acute grade II gut GvHD that was resolved with steroids. Although she had a stable full donor chimerism since day +30 , immune cytopenia (neutropenia and thrombocytopenia) relapsed twice at 6 months and one year post-transplant. She required brief courses of G-CSF and high-dose steroids with complete response. She therefore is currently on immunosuppressive therapy with CSA and MMF at 21 months post- transplant. This regimen has led to a sustained but treatment-dependent remission. The latest respiratory function tests performed after several episodes of upper and lower respiratory tract infections revealed an obstructive pattern, which was evaluated as a post-viral bronchial hyperreactivity. Her post-HSCT LRBA protein expression was found similar to the expression in her parents and healthy control (Fig. 1).

\section{Patient 3}

16-year old male patient born to consanguineous parents became symptomatic at neonatal period. Over time, he developed chronic bloody diarrhea and repeated infections including severe pneumonia and bacterial sepsis. By the age of seven years, he was diagnosed with CVID. Subsequently, IVIG replacement therapy and antibiotic prophylaxis were initiated. Due to further chest symptoms despite this regimen, a chest CT scan performed and bilateral disseminated bronchiectasis and subsegmental atelectasis were observed. Pulmonary function tests revealed a combined obstructive and restrictive pattern. After an episode of diarrhea, he was diagnosed with CMV colitis at colonoscopy and treated with ganciclovir. Repeated colonoscopic exams, which were performed because of refractory chronic diarrhea demonstrated an IBD-like mucosal pattern on biopsy. A combination of immunosuppressive therapy that included steroids, MMF and mesalazine was initiated. During follow up, he manifested growth failure (weight and height for age $<3 p$ ), delayed puberty associated with secondary functional hypogonadism, steroid-induced adrenal insufficiency and osteopenia. Therefore, replacement therapies were started accordingly. His pre-transplant immunology work-up showed an 


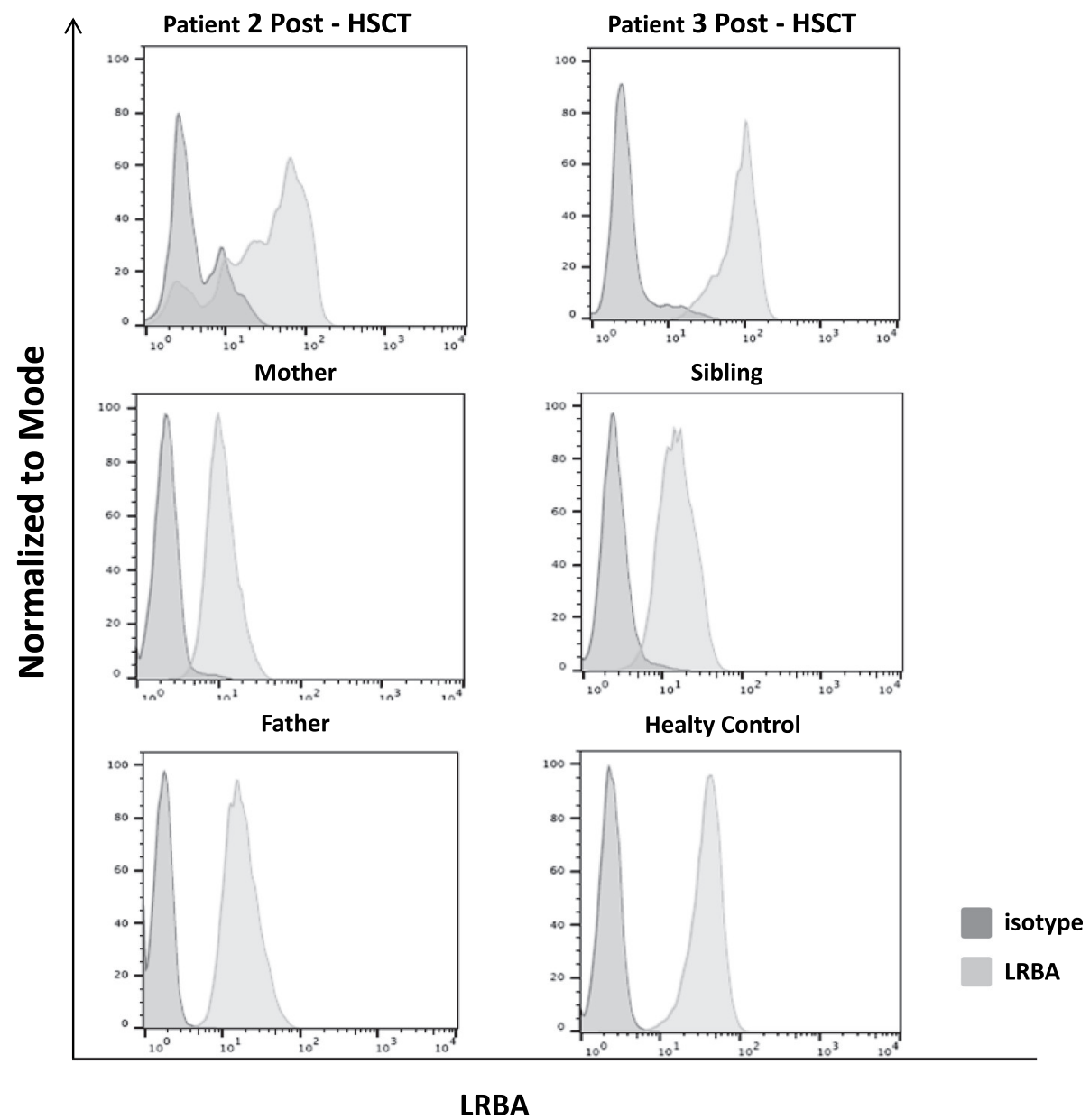

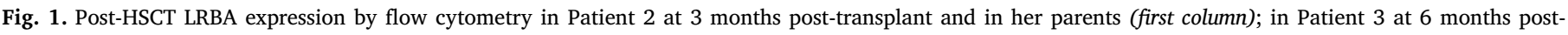
transplant and in his donor compared to an unrelated healthy donor (second column).

almost normal distribution of lymphocytes, except B cell lymphopenia and hypogammaglobulinemia (Table 1). His blood count was normal. Genetic analysis confirmed the presence of LRBA mutation. Due to the increase in severe disease-related problems, HSCT was performed at the age of 16 years with bone marrow stem cells $\left(1.7 \times 10^{8}\right.$ total nucleated cells $/ \mathrm{kg}$ and $4.1 \times 10^{6} \mathrm{CD} 34+$ cells $/ \mathrm{kg}$ ) from his healthy HLA-identical sister after the patient received reduced intensity conditioning regimen including fludarabine $\left(30 \mathrm{mg} / \mathrm{m}^{2} /\right.$ day -8 to -4$)$ and melphalan $\left(70 \mathrm{mg} / \mathrm{m}^{2} /\right.$ day -4 to -3$)$. ATG-F (grafalon) was given day -3 to -1 $(30 \mathrm{mg} / \mathrm{kg}$ ) as GvHD prophylaxis, together with CSA and low-dose methotrexate. Busulfan was omitted from the conditioning regimen due to the significant pulmonary findings prior to transplant. He had an uncomplicated engraftment period (neutrophil and thrombocyte recovery on day +20 and +26 ). Stable donor chimerism was observed beginning from day +30 onward. He stayed off the immunosuppressive therapy one year post-transplant with no signs of GvHD and complete resolution of his disease symptoms. He is now 24 months post-transplant, with a significantly improved pulmonary function and $97 \%$ donor chimerism. Post-HSCT LRBA protein expression in the patient was normal and comparable to the expression in his sibling and healthy control (Fig. 1).

Taken together, we describe the transplant course and outcome of three LRBA deficient patients who presented with severe disease phenotype (Table 2). Allogeneic HSCT led to resolution of majority of the disease-related manifestations in all three patients without any significant transplant-related complications (Table 2). Since our patients had ongoing chronic inflammation and cumulative organ damage, we preferred to use a reduced intensity conditioning and serotherapy with
ATG. Despite that, Patient 1 with active primary disease prior to HSCT had a more complicated early posttransplant period, compared to other two with stable disease. Recurrent cytopenia developed in two patients (P1 and P2) after transplantation, despite full whole blood donor chimerism could be attributed to disease-related immune dysregulation or dysfunctional bone marrow. Of 72 reported patients with LRBA-deficiency, there are twelve cases in whom allogeneic HSCT was performed, with an overall survival of $67 \%(8 / 12)$. Good partial or complete remission was achieved in four patients [3]. Our results are in alignment with the previous reports and confirm that disease-related immune dysregulation and autoimmune manifestations gradually improve after HSCT following immunological recovery, provided a stable engraftment is achieved. However, there are some critical points to be considered such as: i. Careful evaluation of disease-related cumulative organ damage and disease status (active, partially-controlled or stable) prior to HSCT, ii. Selection of optimal conditioning regimen that is tailored to patient comorbidities, iii. Prolonged use of immunosuppressive therapy and antimicrobial prophylaxis including IVIG after transplantation, at least one year in order to reduce the risk of disease-related complications.

In conclusion, allogeneic HSCT could be considered as a reliable treatment option in patients with LRBA deficiency. However, more reports are needed to establish guidelines for allogeneic HSCT. Also, lack of genotype-phenotype correlation in patients with LRBA deficiency makes the discovery of prognostic biomarkers necessary in order to allow identification of candidates for early HSCT, and aid long-term follow-up for optimal outcomes. 
Table 2

Transplanted-related characteristics and outcome of three LRBA deficient-patients who underwent allogeneic HSCT.

\begin{tabular}{|c|c|c|c|}
\hline Patient & Transplant characteristics & Post-HSCT morbidity & Post-HSCT disease status \\
\hline $14 \mathrm{yo} / \mathrm{M}$ & $\begin{array}{l}\text { MSD (heterozygous sibling) } \\
\text { BM graft } \\
\text { BU/FLU/ATG } \\
\text { CSA + low dose-methotrexate }\end{array}$ & $\begin{array}{l}\text { CMV viremia } \\
\text { Pancytopenia } \\
\text { Acute cholecytitis } \\
\text { Acute appendicitis }\end{array}$ & GPR w/full donor chimerism at 36 months post-transplant \\
\hline $18 \mathrm{yo} / \mathrm{F}$ & $\begin{array}{l}\text { MSD (homozygous sibling) } \\
\text { BM graft } \\
\text { BU/FLU/ATG } \\
\text { CSA + low dose-methotrexate }\end{array}$ & $\begin{array}{l}\text { Acute GvHD } \\
\text { Immune cytopenia }\end{array}$ & $\mathrm{PR} \mathrm{w} /$ full donor chimerism at 21 months post-transplant \\
\hline 16 уо/M & $\begin{array}{l}\text { MSD (homozygous sibling) } \\
\text { BM graft } \\
\text { FLU/Mel/ATG } \\
\text { CSA + low dose-methotrexate }\end{array}$ & Uncomplicated transplant course & $\mathrm{CR}$ w/full donor chimerism at 24 months post-transplant \\
\hline
\end{tabular}

MSD: matched sibling donor, BM: bone marrow, CR: complete remission, GPR: good partial remission (mild residual disease-related symptoms, no immunosuppressive therapy), PR: partial remission (residual disease-related symptoms, immunosuppressive therapy needed).

\section{Acknowledgements}

We are thankful to Prof. Dr. Ahmet Ozen and Pediatric Immunology Flow cytometry Laboratory at Marmara University for analyses of postHSCT LRBA expression in patients' samples.

\section{COI statement}

"Authors declare that they have no conflict of interest."

\section{References}

[1] G. Lopez-Herrera, G. Tampella, Q. Pan-Hammarstrom, et al., Deleterious mutation in LRBA are associated with a syndrome of immunodeficiency and autoimmunity, Am. J. Hum. Genet. 90 (2012) 986-1001.

[2] B. Lo, K. Zhang, W. Lu, et al., Patients with LRBA deficiency show CTLA4 loss and immune dysregulation responsive to abatacept therapy, Science 349 (6246) (2015) 436-440.

[3] M.G. Seidel, K. Bőhm, F. Dogu, et al., Treatment of severe forms of LPS-responsive beige-like anchor protein deficiency with allogeneic hematopoietic stem cell transplantation, J. Allergy Clin. Immunol. 141 (2018) 770-771.

[4] L. Gamez-Diaz, D. August, P. Stepensky, et al., The extended phenotype of LPS-responsive beige-like anchor protein (LRBA) deficiency, J. Allergy Clin. Immunol. 137
(2016) 223-230.

[5] M.G. Seidel, T. Hirschmugl, G. Lopez-Herrera, et al., Long term remission after allogeneic hematopeitic stem cell transplantation in LPS-responsive beige-like anchor (LRBA) deficiency, J Allergy Clin Immunology 135 (5) (2015) 1384-1390.

[6] B. Tesi, P. Priftakis, F. Lindgren, et al., Successful hematopoietic stem cell transplantation in a patient with LPS-responsive beige-like anchor (LRBA) gene mutation, J. Clin. Immunol. 36 (2016) 480-489.

[7] S. Bakhtiar, L. Gamez-Diaz, A. Jarisch, et al., Treatment of infantile inflammatory bowel disease and autoimmunity by allogeneic stem cell transplantation in LPS-responsive beige-like anchor deficiency, Front. Immunol. 8 (2017) 1-9.

[8] S. Kostel Bal, S. Haskologlu, N.K. Serwas, et al., Multiple presentations of LRBA deficiency: a single-center experience, J. Clin. Immunol. 37 (2017) 790-800.

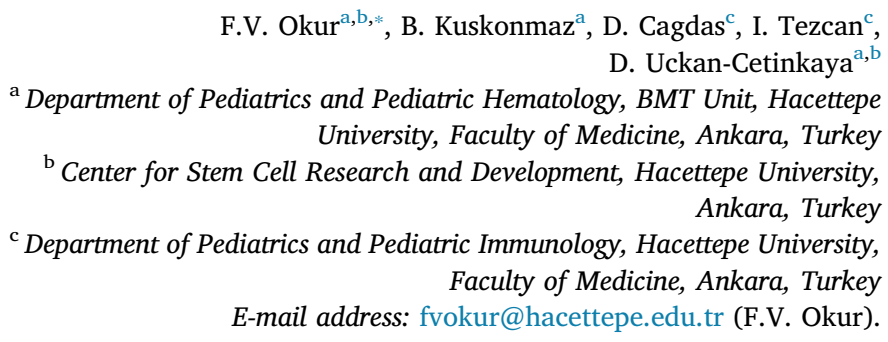

* Corresponding author at: Department of Pediatrics and Pediatric Hematology, BMT Unit, Hacettepe University, Faculty of Medicine, Ankara, Turkey. 